\title{
EFEKTIFITAS TERAPI MUROTTAL TERHADAP PENURUNAN TINGKAT NYERI PADA PASIEN KANKER
}

\author{
AmiaRosandi Suwardi ${ }^{1}$, Desi Ariyana Rahayu ${ }^{2}$ \\ ${ }^{1}$ Program Studi S1 Keperawatan Fikkes Universitas Muhammadiyah Semarang \\ ${ }^{2}$ Keperawatan Jiwa Fikkes Universitas Muhammadiyah Semarang \\ desi.ariyana@unimus.ac.id
}

\begin{abstract}
ABSTRAK
Nyeri adalah keluhan yang umum pasca pengobatan bagi penderita kanker, bahkan bertahun-tahun setelah pengobatan. Pengendalian nyeri dapat dilakukan dengan pengobatannon farmakologis, diantaranya menggunakan terapi murottal yaitu terapi dengan mendengarkan alunan ayat-ayat suci alqur'an yang dibacakan oleh 'qori. Tujuan penelitian untuk mengetahui efektifitas terapi musik klasik dengan terapi murottal terhadap penurunan tingkat nyeri pada pasien kanker. Jenis penelitian Quasy Eksperimental dengan menggunakan bentuk rancangan three group pre and post test with kontrol design. Populasi dalam penelitian ini adalah pasien kanker yang mengalami nyeri. Sampel berjumlah 75 responden dengan menggunakan teknik purposive sampling, yang terdiri dari kelompoki ntervensi dan kelompok kontrol. Analisis data dengan menggunakan Kruskal Wallis dan Wilcoxon. Hasil penelitian menunjukkan bahwa rata-rata tingkat nyeri pada kelompok intervensi sesudah diberikan terapi murottal sebesar 13,00. Hal ini menujukkan terjadinya penurunan tingkat nyeri setelah diberikan terapi murottal. Ada pengaruh pemberian terapi murottal terhadap penurunan tingkat nyeri pada pasien kanker di Rumah Sakit Islam Sultan Agung Semarang dengan nilai $\mathrm{p}=0,000$ ( $\mathrm{p}$-value<0.05). Penelitian ini memberikan rekomendasi kepada perawat, pasien kanker, mahasiswa agar dapat membantu memenuhi kebutuhan diri akan rasa nyaman dalam pengontrolan nyeri.
\end{abstract}

Kata kunci : Terapi musik klasik, terapi murottal, kanker, tingkat nyeri

\section{EFFECTIVENESS OF MUROTTAL THERAPY IN DECREASING PAIN LEVEL OF CANCER PATIENTS}

\begin{abstract}
Pain is a common complaint post-treatment for cancer sufferers, even years after treatment. Pain kontrol can be done by non pharmacological treatment, including using murottal therapy is therapy by listening to the strains of holy verses of the Qur'an which is read by 'Qori. Research objectives to determine the effectiveness of classical musik therapy with murottal therapy to decrease the level of pain in cancer patients. Types of experimental Quasy research using the design form Three Group Pre and Post Test with Kontrol Design. The population in this study is a cancer patient who is experiencing pain. Samples numbered 75 respondents using the purposive sampling technique, consisting of intervention groups and kontrol groups. Data analysis using Kruskal Wallis and Wilcoxon. The results showed that the average level of pain in the intervention group after Murottal therapy was 13,00. This shows the occurrence of pain reduction after being given murottal therapy. There is an influence on the treatment of murottal to decrease the level of pain in cancer patients in the Islamic hospital Sultan Agung Semarang with a value $P=0,000(P$-value $<0.05)$. The study provided recommendations to nurses, cancer patients, students in order to help meet the self-need for comfort in pain kontrol.
\end{abstract}

Keywords: Classic musik therapy, murottal therapy, cancer, the level of pain

\section{PENDAHULUAN}

Kanker adalah penyebab utama kematian kedua secara global dan diperkirakan mencapai 9,6 juta kematian pada tahun 2018. Kanker paru-paru, prostat, kolorektal, perut dan hati adalah jenis kanker yang paling umum pada pria, sementara payudara, kolorektal, paru-paru, leher rahim dan kanker tiroid adalah yang paling umum di antara wanita (World Health Organization, 2018). 
Jumlah penderita kanker di Indonesia sangat tinggi. Hal ini terlihat dari berbagai data kanker yang telah dipublikasikan baik oleh pemerintah maupun lembaga-lembaga kanker. Bahkan menurut WHO pada tahun 2030 akan terjadi peningkatan penderita kanker di Indonesia sampai tujuh kali lipat. Kanker payudara dan kanker serviks merupakan jenis kanker yang tertinggi prevalensinya pada perempuan di Indonesia. Kedua kanker ini dapat ditemukan pada tahap yang lebih dini, akan tetapi saat ini kanker lebih sering diketahui pada stadium lanjut $(70 \%)$ sehingga angka kematiannya tinggi. Itu membuat kanker serviks disebut sebagai penyakit pembunuh wanita nomor satu di Indonesia (Kemenkes, 2018).

Sampai dengan tahun 2017 sudah dilakukan deteksi dini kanker serviks dan payudara terhadap 3.040.116 perempuan usia 30-50 tahun $(2,98 \%)$ di Indonesia. Pemeriksaan dilakukan menggunakan metode Pemeriksaan Payudara Klinis (SADANIS) untuk deteksi dini kanker payudara dan pemeriksaan Inspeksi Visual Asam Asetat (IVA) atau Pap Smear untuk deteksi dini kanker serviks. Cakupan pemeriksaan deteksi dini kanker serviks dan payudara pada perempuan usia 30-50 tertinggi terdapat di Bangka Belitung yaitu sebesar 13,19\%, diikuti oleh Sumatera Barat sebesar 9,34\%, dan Kalimantan Selatan sebesar 8,77\%. Hasil pemeriksaan deteksi dini kanker leher rahim dan payudara di Indonesia, dimana sampai dengan tahun 2017 telah ditemukan 105.418 IVA positif, 12.023 tumor payudara, 3.601 curiga kanker leher rahim, dan 3.079 curiga kanker payudara (Kemenkes, 2018).

Salah satu pengobatan penyakit kanker secara sistemik adalah kemoterapi. Namun kemoterapi memiliki efek samping karena obat kemoterapi yang digunakan tidak hanya menghancurkan sel-sel kanker tetapi juga menyerang sel-sel sehat, terutama sel-sel yang membelah dengan sangat cepat. Efek yang muncul pada pasien yang menjalani kemoterapi adalah respon fisik dan fisiologis. Respon fisik yang dialami diantaranya adalah mual dan muntah, kerontokan pada rambut (alopecia) dan nyeri (Raphael, 2010).
Nyeri adalah keluhan yang umum pasca pengobatan bagi penderita kanker, bahkan bertahun-tahun setelah pengobatan. Nyeri kanker sering ditemukan dalam praktek sehari-hari pada pasien yang pertama kali datang berobat, sekitar 30\% pasien kanker disertai dengan keluhan nyeri dan hampir $70 \%$ pasien kanker stadium lanjut yang menjalani pengobatan, ternyata pada $20 \%$ penderita yang mendapat pengobatan, timbul keluhan nyeri bukan disebabkan penyakit yang dideritanya, tetapi justru dari pengobatan yang telah didapatkannya (Gartner, 2011). Pengendalian nyeri dapat dilakukan secara farmakologis dan non farmakologis. Dengan berkembangnya Ilmu Pengetahuan dan Teknologi (IPTEK) dimasa sekarang, banyak ditemukan terapi komplementer dan holistik non farmakologis dikalangan keperawatan. Terapi non farmakologis yang dapat menurunkan nyeri antara lain teknik relaksasi, terapi suara, dan aroma terapi (Suwanto, et al, 2016).

Terapi musik merupakan salah satu terapi komplementer non invasif yang dapat digunakan dalam menurunkan intensitas nyeri. Beberapa penelitian membuktikan bahwa musik memiliki pengaruh yang besar pada kehidupan manusia. Para ahli mengemukakan bahwa musik bisa berpengaruh pada kecerdasan manusia, kesehatan fisik, mental dan emosional.

\section{METODE}

Rancangan penelitian ini adalah Quasy Experimental design dengan jenis Non equivalent Kontrol Group Design. Subyek dalam penelitian ini adalah pasien kanker di Rumah Sakit Islam Sultan Agung yang mengalami nyeri. Melalui teknik purposive sampling, maka didapatkan 75 orang yang memenuhi kriteria inklusi, yang kemudian terbagi menjadi 3 kelompok yaitu 2 kelompok intervensi dan 1 kelompok kontrol. Ketiga kelompok dilakukan pengkajian tingkat nyeri sebelum dan sesudah tindakan pada kelompok intervensi 1 yaitu dengan menggunakan terapi musik klasik, kelompok intervensi 2 dengan menggunakan terapi murottal, sedangkan kelompok kontrol tidak dilakukan perlakuan. Tingkat nyeri diukur dengan Numeric Rating Scale. 


\section{HASIL}

Penelitian ini dilakukan pada pasien kanker yang mengalami nyeri di Rumah Sakit Islam Sultan Agung. Pemilihan lokasi penelitian didasarkan pada jumlah pasien, homogenitas, dan kemudahan perlakuan dan pengamatan dalam penelitian. Pengambilan subyek dilakukan selama satu bulan yaitu pada bulan Februari 2019 sampai dengan Maret 2019 sebanyak 75 subyek yang terbagi dalam 3 kelompok, yaitu 25 subyek masuk ke dalam kelompok perlakuan terapi musik klasik, 25 subyek masuk ke dalam kelompok perlakuan terapi murottal dan 25 subyek masuk ke dalam kelompok kontrol dimana dalam kelompok ini subyek penelitian tidak mendapat perlakuan. Dilakukan pre test (pengukuran awal) nyeri dengan menggunakan Numeric Rating Scale terlebih dahulu sebelum diberikan atau tanpa diberikan terapi. Setelah itu, pada kelompok eksperimen 1 diberikan terapi musik klasik Piano Sonata No.11 in A Mayor, K.331 by Mozart dan kelompok eksperimen 2 diberikan terapi murottal surat Ar-Rahman by Sheikh Mishary Rasyid dua kali setiap hari selama 21 hari berturut-turut dengan durasi waktu 15 menit dengan volume 50 desibel, kemudian pada minggu ketiga dilakukan post test (pengukuran akhir) untuk mendapatkan hasil setelah diberikan terapi musik klasik, terapi murottal dan tanpa diberikan terapi.Setiap subyek penelitian diberikan informed concent dan dimintakan ijin penelitian kepada subyek penelitian.

Tabel 1.

Rata-rata tingkat nyeri sebelum dan sesudah diberikan terapi musik klasik $(\mathrm{n}=25)$

\begin{tabular}{lccccc}
\hline Intervensi & Min & Max & Mean & SD \\
\hline Tingkat nyeri sebelum diberikan terapi musik klasik & 4 & 7 & 5.40 & 0.764 \\
Tingkat nyeri sesudah diberikan terapi musik klasik & 3 & 6 & 4.72 & 0.737 \\
\hline
\end{tabular}

Berdasarkan tabel 1 diketahui bahwa rata-rata tingkat nyeri sebelum diberikan terapi musik

klasik sebesar $5,40 \pm 0,764$ dan sesudah memiliki rata-rata sebesar $4,72 \pm 0,737$.

Tabel 2

Rata-rata tingkat nyeri sebelum dan sesudah diberikan terapi murottal $(\mathrm{n}=25)$

\begin{tabular}{lcccc}
\hline Intervensi & Min & Max & Mean & SD \\
\hline Tingkat nyeri sebelum diberikan terapi murottal & 5 & 7 & 5.80 & 0.764 \\
Tingkat nyeri sesudah diberikan terapi murottal & 2 & 5 & 3.84 & 0.800 \\
\hline
\end{tabular}

Berdasarkan tabel 2 diketahui bahwa rata-rata tingkat nyeri sebelum diberikan terapi murottal

sebesar $5,80 \pm 0,764$ dan sesudah memiliki rata-rata sebesar $3,84 \pm 0,800$.

Tabel 3.

Rata-rata tingkat nyeri sebelum dan sesudah pada kelompok kontrol $(n=25)$

\begin{tabular}{|c|c|c|c|c|}
\hline Intervensi & Min & $\operatorname{Max}$ & Mean & SD \\
\hline Tingkat nyeri sebelum pada kelompok kontrol & 3 & 6 & 4.68 & 0.852 \\
\hline Tingkat nyeri sesudah pada kelompok kontrol & 3 & 6 & 4.80 & 0.866 \\
\hline $\begin{array}{l}\text { Berdasarkan tabel } 3 \text { diketahui bahwa rata-rata } \\
\text { tingkat nyeri sebelum pada kelompok kontrol }\end{array}$ & & & $\begin{aligned} & \text { da } \\
= & 0,86\end{aligned}$ & \\
\hline
\end{tabular}

Tabel 4.

Hasil Uji Normalitas ( $n=75)$

\begin{tabular}{lccc}
\hline \multirow{2}{*}{ Kelas } & \multicolumn{3}{c}{ Shapiro-Wilk } \\
\cline { 2 - 4 } & Statistic & Df & Sig. \\
\hline Pre test Terapi Musik Klasik & .846 & 25 & .001 \\
Post test Terapi Musik Klasik & .782 & 25 & .000 \\
Pre test Terapi Murottal & .797 & 25 & .000 \\
Post test Terapi Murottal & .862 & 25 & .003 \\
Pre test Kelompok Kontrol & .877 & 25 & .006 \\
Post test Kelompok Kontrol & .867 & 25 & .004 \\
\hline
\end{tabular}


Berdasarkan tabel 4 di atas dapat diketahui hasil uji normalitas pada kolom Saphiro-Wilk nilai probabilitas data yang didapatkan terdistribusi normal karena semua data memiliki nilai probabilitas $p<0,05$.

Tabel 5.

Perbedaan tingkat nyeri setelah diberikan terapi musik klasik, terapi murottal dan tanpa diberikan terapi $(\mathrm{n}=75)$

\begin{tabular}{lccc}
\hline & Mean & Chi-Square & Sig. \\
\hline Post Test Terapi Musik Klasik & 44.40 & & \\
Post Test Terapi Murottal & 23.92 & 17.791 & 0.000 \\
Post Test Kelompok Kontrol & 45.68 & & \\
\hline Berd
\end{tabular}

Berdasarkan tabel 5 pada Uji Kruskal Wallis di atas didapatkan hasil dimana nilai probabilitas $p=0,000$ atau nilai $p<0,05$ maka terdapat perbedaan tingkat nyeri setelah diberikan terapi musik klasik, terapi murottal dan tanpa diberikan terapi.

Tabel 6.

Perbedaan tingkat nyeri sebelum dan sesudah dilakukan terapi musik klasik $(\mathrm{n}=25)$

\begin{tabular}{lccc}
\hline \multicolumn{1}{c}{ Intervensi } & Mean & $\mathrm{Z}$ & p-value \\
\hline Tingkat nyeri sebelum diberikan terapi musik klasik & 0.00 & -3.690 & \multirow{2}{*}{0.000} \\
Tingkat nyeri sesudah diberikan terapi musik klasik & 8.00 & & \\
\hline
\end{tabular}

Berdasarkan tabel 6 hasil uji statistik dengan uji wilcoxon (uji 2 related samples) dapat dijelaskan bahwa rata-rata tingkat nyeri pada kelompok intervensi sesudah diberikan terapi musik klasik sebesar 8.00. Hasil uji wilcoxon (uji 2 related samples) diatas didapatkan $p$ value $=0.000<0.05$, dengan demikian dapat disimpulkan bahwa ada perbedaan tingkat nyeri sebelum dan sesudah diberikan terapi musik klasik pada pasien kanker.

Tabel 7.

Perbedaan tingkat nyeri sebelum dan sesudah dilakukan terapi murottal

\begin{tabular}{|c|c|}
\hline Intervensi & $p$-value \\
\hline Tingkat nyeri sebelum diberikan terapi murottal & -4.477 \\
\hline Tingkat nyeri sesudah diberikan terapi murottal & 13.00 \\
\hline $\begin{array}{l}\text { Berdasarkan tabel } 7 \text { hasil uji statistik dengan } \\
\text { uji wilcoxon (uji } 2 \text { related samples) dapat } \\
\text { dijelaskan bahwa rata-rata tingkat nyeri pada } \\
\text { kelompok intervensi sesudah diberikan terapi } \\
\text { murottal sebesar } 13.00 \text {. Hasil uji wilcoxon (uji }\end{array}$ & $\begin{array}{l}2 \text { related samples) diatas didapatkan } p \text { - } \\
\text { value }=0.000<0.05 \text {, dengan demikian dapat } \\
\text { disimpulkan bahwa ada perbedaan tingkat } \\
\text { nyeri sebelum dan sesudah diberikan terapi } \\
\text { murottal pada pasien kanker. }\end{array}$ \\
\hline
\end{tabular}

Tabel 8

Perbedaan tingkat nyeri sebelum dan sesudah pada kelompok kontrol tanpa diberikan terapi $(n=25)$

\begin{tabular}{lccc}
\hline Intervensi & Mean & $\mathrm{Z}$ & p-value \\
\hline Tingkat nyeri sebelum pada kelompok kontrol tanpa diberikan terapi & 0.00 & -1.732 & 0.083 \\
Tingkat nyeri sesudah pada kelompok kontrol tanpa diberikan terapi & 2.00 & & \\
\hline
\end{tabular}

Berdasarkan tabel 4.8hasil uji wilcoxon (uji 2 related samples) dapat dijelaskan bahwa ratarata tingkat nyeri sesudah pada kelompok kontrol tanpa diberikan terapi sebesar 2.00. Hasil uji wilcoxon (uji 2 related samples) diatas didapatkan $p$-value $=0.083>0.05$, dengan demikian dapat disimpulkan bahwa tidak ada perbedaan tingkat nyeri sebelum dan sesudah pada kelompok kontrol tanpa diberikan pada pasien kanker.

\section{PEMBAHASAN}

Perbedaan tingkat nyeri sebelum dan sesudah diberikan terapi musik klasik pada kelompok intervensi

Berdasarkan hasil analisis dapat diambil kesimpulan bahwa terapi musik klasik memberikan hasil penurunan nyeri sedang ke nyeri ringan. Namun terapi musik klasik tidak menunjukkan hasil yang signitifkan karena rata-rata responden baru pertama kali 
mendengarkan dan merasa asing dengan musik klasik tersebut sehingga terapi musik klasik hanya memberikan efek rasa rileks saja tanpa mengandung makna dalam musik tersebut.

Hal tersebut didukung oleh pendapat Sesrianty dan Wulandari (2018) menyatakan bahwa setalah tiga kali pemberian terapi musik klasik ditemukan responden yang mulanya dengan rata-rata skala nyeri pada tingkat berat terjadi penurunan rata-rata skala nyeri pepada tingkat sedang. Musik merupakan intervensi yang efektif untuk meningkatkan relaksasi fisiologis serta memberikan stimulus yang unik yang bisa mempengaruhi respon fisik dan psikologi pendengar (Herawati, et all, 2018).

Tinjauan teori menyebutkan bahwa sebagian besar pasien yang mengalami kanker yang menyebut nyeri akut sebagai gejala primer yang menimbulkan diagnosis, cenderung menghubungkan nyeri dengan permulaan penyakit yang mereka alami. Jika pasien tersebut mengalami nyeri selama sakit atau setelah terapi, mereka seringkali menerima nyeri sebagai permulaan kanker lain, kekambuhan kanker asli atau komponen terapi kanker (LeMone, et all, 2016).

Perbedaan tingkat nyeri sebelum dan
sesudah diberikan terapi murottal pada
kelompok intervensi Berdasarkan hasil analisis dapat diambil kesimpulan terapi murottal menunjukkan hasil bahwa tingkat nyeri mengalami penurunan yang drastis dari nyeri berat ke nyeri ringan. Hal tersebut dikarenakan terapi murottal memberikan nilai spiritual yang membuat jiwa menjadi tenang dengan mengeluarkan tetesan air mata serta rileks yang begitu dalam dan seakan merasakan ada energi baru pada tubuhnya. Selain itu surat ar-rahman juga memiliki karakter ayat yang pendek serta terdapat beberapa pengulangan ayat sehingga surat ini bisa mudah dipahami.

Hal tersebut didukung oleh pendapat Rahayu, Hidayati \& Imam (2018). menyatakan bahwa setelah diberikan terapi murottal tingkat depresi sedang turun menjadi tingkat depresi ringan. Selain itu hasil penelitian Faradisi \& Aktifah (2018) tentang pengaruh pemberian terapi murottal terhadap penurunan kecemasan post operasi didapatkan hasil secara statistik dengan $p=0,004$ artinya adanya pengaruh pemberian terapi murottal terhadap penurunan kecemasan post operasi.

\section{Perbedaan tingkatsebelum dan sesudah pada kelompok kontrol tanpa diberikan terapi}

Berdasarkan hasil penelitian dapat diketahui bahwa pada kelompok kontrol yang tidak diberikan terapi sebelum perlakuan rata-rata tingkat nyeri sesudah pada kelompok kontrol tanpa diberikan terapi sebesar 2.00. Hal ini menujukkan terjadinya peningkatan tingkat nyeri setelah pada kelompok kontrol tanpa diberikan terapi. Berdasarkan uji wilcoxon, didapatkan nilai $\mathrm{p}$ value sebesar 0.083 (p> 0.05), ini menunjukkan bahwa tidak ada perbedaan yang signifikan antara tingkat nyeri sebelum dan sesudah pada kelompok kontrol pada pada pasien kanker.

Nyeri merupakan keyakinan individu dan bagaimana respon individu tersebut terhadap sakit yang dialaminya (Taylor, 2011). Faktor yang dapat menjadi penyebab dari timbulnya nyeri kanker pada umumnya diantaranya yaitu nyeri yang disebabkan langsung oleh tumor yang menyebabkan kompresi saraf sentral maupun perifer, nyeri akibat pengobatan kanker seperti kemoterapi menyebabkan neuropati dan nekrosis jaringan menimbulkan nyeri, nyeri yang tidak berhubungan dengan tumor biasanya tergantung kondisi pasien yang mengalami distensi lambung, infeksi, nyeri muskuloskeletal (Desen, Wan \& Japaries, 2013).

Hasil penelitian tentang efektifitas terapi musik klasik dengan terapi murottal terhadap penurunan tingkat nyeri pada pasien kanker didapatkan hasil pasien dengan terapi murottal merasakan rileks yang begitu dalam, mendapatkan ketenangan jiwa, sehingga ada dorongan energi baru dan dorongan motivasi untuk menghadapi masalah yang dihadapi dengan mengingat tuhan dan terjadi perubahan yang mendadak drastis pada fisiologis dan psikologis sehingga dapat memberikan rasa nyaman dan tenang. Peneliti juga tidak menemukan hasil penelitian yang lain yang bertentangan dengan hasil temuan di atas. Ini menunjukkan bahwa kemungkinan terapi murottal merupakan jenis terapi nonfarmakologi yang sudah terbukti secara 
empiris untuk mengatasi nyeri yang juga dapat dibuktikan efektif secara ilmiah untuk mengatasi nyeri.

\section{SIMPULAN DAN SARAN \\ Simpulan}

Penelitian ini memberikan hasil bahwa setelah diberikan intervensi dengan terapi musik klasik, terapi murottal dan tanpa diberikan terapi, terapi murottal menunjukkan penurunan tingkat nyeri yang sangat signifikan, artinya terapi murottal lebih efektif dan berperan dalam menurunkan tingkat nyeri

\section{Saran}

Rekomendasi hasil penelitian ini perawat bias memberikan pendidikan kesehatan atau membuat leaflet untuk membantu memenuhi kebutuhan pasien kanker dalam pengontrolan nyeri secara non farmakologis.

\section{DAFTAR PUSTAKA}

Desen, Wan \& Japaries, W. (2013). Buku Ajar Onkologi Klinis (2nd ed.). Jakarta: FKUI.

Faradisi, F., \& Aktifah, N. (2018). Pengaruh Pemberian Terapi Murottal Terhadap Penurunan Kecemasan Post Operasi. Jurnal Keperawatan, 15(2), 1-5.

Gartner, A. M. (2011). The Elkins Distress Inventory: Development of Brief Biopsychococial Distress in a Chronic Pain Population.

Herawati, N., Sari, K., \& M. (2018). Pengaruh Terapi Musik Klasik Terhadap Penurunan Tekanan Darah pada Lansia dengan Hipertensi. Jurnal Keperawatan, 12(3), 91-97.

Kemenkes. (2018). Health Statistics. Jakarta: Kemenkes RI.

LeMone, P., Burke, K. M., \& Bauldoff, G. (2016). Keperawatan Medikal Bedah. Jakarta: EGC.

Rahayu, D. A., Hidayati, T. N., \& Imam, T. A. (2018). The Effect of Murottal Therapy in Decreasing Depression of Patients Undergoing Hemodialysis. Media Keperawatan Indonesia, 1(2), 6.

Raphael. (2010). Cancer pain: Part 1: Pathophysiology, Oncological, Pharmacological, and Psychological Treatmens. Journal of Pain Medicine, $11,742-764$.

Sesrianty, V., \& Wulandari, S. (2018). Terapi Musik Klasik (Alunan Piano) Menurunkan Intensitas NRS ( Numeric Rating Scale ), 1(1).

Suwanto, Basri, A.H \& Umalekhoa, M. (2016). Efektivitas Terapi Musik Klasik dan Terapi Murottal Untuk Menurunkan Tingkat Kecemasan pada Pasien Pre Operasi. Jurnal Keperawatan, 7.

Taylor, C., Lillis, C., Lemone, P., \& Lynn, P. (2011). Fundamental of Nursing The Art and Science of Nursing Care Seventh Edition. China: Wolters Kluwer Health. 